\title{
The Impact Of The Sarbanes-Oxley Act Of 2002 On The Teaching Of Ethics In Core MBA Curriculums In Ohio
}

Daniel W. Sullivan, Ashland University, USA

\begin{abstract}
A decade of corporate scandals has highlighted a lack of ethical decision making skills among business leaders. Reasons for this deficiency vary from an absence of ethical teaching in the home to a failure of American corporate culture. In 2002, the situation reached a critical point with scandals such as Enron and Tyco forcing a Congressional response in the form of the SarbanesOxley Act of 2002. Questions concerning corporate leaders' ability to act ethically again resurfaced in the wake of the recent financial collapse of giants such as AIG and Citigroup, creating a debate over what lessons were learned from the Sarbanes- Oxley experience. MBA curriculums are major stakeholders in this debate. MBA programs are venues where the majority of our business leaders learn the critical skills needed to succeed. The purpose of this study was to assess the treatment of ethics in core MBA curriculums in Ohio in response to the SarbanesOxley Act of 2002. The study determined that MBA programs in Ohio failed to adjust their core curriculums in response to the new demand for increased ethics instruction. Further, it determined that private and public institutions reacted to the legislation in a similar manner. It also revealed that private and public institutions traditionally approach ethics instruction differently.
\end{abstract}

Keywords: Sarbanes-Oxley, business ethic, ethics instruction, MBA programs

\section{INTRODUCTION}

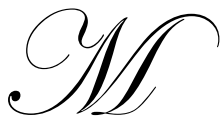

BA programs, through their positions of stature within the academic and business communities bear a heavier burden in teaching ethics to students than do undergraduate business institutions. Devaney (2007) stated that an MBA education may not indicate that an individual is a competent leader or has good business intuition but it does indicate that he or she has been provided a "manager's tool box" of skills which can be called upon when the need arises. Businesses place a high premium on the existence of these skills in their hiring decisions. A study conducted by the Leadership Initiative at the Harvard School of Business found that $60 \%$ of the business leaders in large American companies in the 1990's had MBA degrees (Devaney, 2007). Often the existence of an MBA on a candidate's resume is the deciding factor in the job selection process.

Because of the high esteem business leaders hold for candidates with MBA degrees, these programs share a unique responsibility for the ethical scandals prevalent at the beginning of this decade (Ghoshal, 2005). Congressional response to these ethics based corporate scandals resulted in the passage of the Sarbanes-Oxley Act of 2002. Sadly, recent issues of mismanagement in large institutions such as AIG and Citigroup bear testament to the fact that more work needs of be done. Some experts contend that the failure of MBA programs to instill ethical standards of conduct in their students through relevant curriculums places the responsibility for unethical business practices squarely at their door (Ghoshal, 2005: Mintzberg, 2004; Pfeffer \& Fong, 2002).

MBA programs vary widely in their handling of curriculum (Leonard, 2001). Even traditional mainstays of most MBA curriculums such as finance, economics, and marketing vary from program to program. Some programs specialize in finance and marketing while others specialize in economics, industrial relations, or other disciplines 
(Segev, Raveh, \& Farjoun, 1999). In this varied environment, it is not surprising that a uniform approach to teaching business ethics does not exist. Some institutions teach ethics using a team approach or as a required course for first year students (Alsop, 2003; Friedman, 1996). Other institutions teach students a code of ethics in their first year of study and require them to abide by its provisions as a condition of continued enrollment (Alsop, 2003). Lastly, some institutions fail to recognize the relationship that exists between teaching ethics and workplace behavior. They choose instead to meet only the minimum standards on ethics instruction established by accreditation organizations ( Beggs \& Dean, 2007; Ghoshal, 2003).

MBA programs are venues that teach students the essential skills needed to succeed in business through the use of a core curriculum that is supplemented by elective courses. In response to the mandates of the SarbanesOxley legislation and in the wake of the recent business scandals of 2008, many business organizations have increased their emphasis on ethical leadership skills. Some have even shifted their hiring policies toward candidates that possess strong ethical values. The purpose of this study was to assess the treatment of ethics in core MBA curriculums in Ohio in response to the passage of the Sarbanes-Oxley Act of 2002; a watershed event illustrating public intolerance of unethical business practices.

\section{SUMMARY OF THE METHODOLOGY}

This study sought to determine if Ohio's MBA programs viewed the Sarbanes-Oxley Act of 2002 as an event which triggered a need for additional ethical skills among their graduates. In order to accomplish this task, baseline period data were collected by examining the written documentation found in MBA program catalogues (2000 thru 2001 academic years). These catalogs described core program curriculums before the passage of the Sarbanes-Oxley Act. The current position of institutions on the issue was determined by repeating this process for the 2008-2009 academic year. Second, individuals selected by their institutions as being most qualified to answer questions on curriculum were interviewed (here after referred to as MBA administrators). These interviews increased the understanding of their institution's reaction to Sarbanes-Oxley legislation and the treatment of ethics in their core curriculums.

A basic qualitative research design was chosen for this study because it was seeking to understand the impact of a particular phenomenon (Merriam, 1998), the passage of the Sarbanes-Oxley Act of 2002, on MBA core curriculums in Ohio. The following two research questions were used to gain this understanding.

Research Question 1: Have MBA programs in Ohio adjusted their core curriculums to include more ethical content in response to the Sarbanes-Oxley Act of 2002?

Research Question 2: Have private colleges and universities in Ohio adjusted their core curriculums in a manner that differs from public institutions in response to the demand for more ethics instruction?

Institutions offering MBA degrees in Ohio were identified using the internet website http://www.findmba.com/ohio. Only institutions with a longstanding campus presence were included in the study. This selection criterion was used to eliminate from the study national or regional institutions offering MBA degrees in Ohio via the internet. Twenty-seven institutions were identified through this process. Eleven of these institutions were state sponsored public universities (Table 1) and 16 were private colleges and universities (Table 2). This sample size ensured that a large variety of institutional positions were considered, positions that would likely be found anywhere in the United States.

A constant comparative data analysis was used for this study. The results of this effort enabled the researcher to construct themes and identify reoccurring patterns in the data that explained the response of Ohio MBA programs to the legislation. To ensure the validity of this study Maxwell's (1992) validity model was used. This model required the researcher to consider issues of internal validity through Maxwell's sub-grouping of descriptive validity, interpretive validity, theoretical validity, and internal generalizability. Issues of reliability or external generalizability are addressed through sample size. 


\section{SUMMARY OF RESULTS}

In response to the first research question, the study found that MBA programs in Ohio did not adjust their core curriculums in response to the Sarbanes-Oxley legislation. Study data showed that although the ethical content of core curriculums in some institutions did change after the passage of the Act, the Sarbanes-Oxley Act was not an influencing factor. Among the 27 institutions included in the study, none cited the Act as a curriculum altering event. Three institutions did add an ethics class to their core curriculums after 2002, however, their MBA program administrators cited other factors, such a need to balance the curriculum or the need to better align their curriculum with institutional objectives, as reasons for the change.

Table 1: Ohio Public Institutions and their Approach to Teaching Ethics

\begin{tabular}{llll}
\hline & & & \\
Base & & Status of Ethics in Core Curriculum \\
\cline { 3 - 4 } Year & Institution & Base Period & $2008-2009$ \\
\hline $2000-2$ & Bowling Green State University & Separate Class & Separate Class \\
$2001-2$ & Cleveland State University & Integrated & Integrated \\
$2000-1$ & Kent State University & Separate Class & Separate Class \\
$2001-2$ & Miami University & Elective & Elective \\
$2000-1$ & Ohio University & Integrated & Integrated \\
$2000-1$ & The University of Akron & Integrated & Integrated \\
$2000-1$ & The Ohio State University & Integrated & Integrated \\
$2000-1$ & The University of Toledo & Integrated & Integrated \\
$2000-1$ & University of Cincinnati & Integrated & Separate Class \\
$2000-1$ & Wright State University & Integrated & Separate Class \\
$2000-1$ & Youngstown State University & Integrated & Integrated \\
\hline
\end{tabular}

Table 2: Ohio Private Institutions and their Approach to Teaching Ethics

\begin{tabular}{|c|c|c|c|}
\hline \multirow{2}{*}{$\begin{array}{l}\text { Base } \\
\text { Year }\end{array}$} & \multirow[b]{2}{*}{ Institution } & \multicolumn{2}{|c|}{ Status of Ethics in Core Curriculums } \\
\hline & & Base Period & $2008-2009$ \\
\hline $2000-1$ & Ashland University & Separate Class & Separate Class \\
\hline $2000-2$ & Baldwin-Wallace College & Separate Class & Separate Class \\
\hline $2000-1$ & Capital University & Separate Class & Separate Class \\
\hline $2000-1$ & Case Western Reserve University & Integrated & Integrated \\
\hline $2000-1$ & Franciscan University & Separate Class & Separate Class \\
\hline $2000-1$ & Franklin University & Separate Class & Separate Class \\
\hline $2001-2$ & Heidelberg College & Separate Class & Separate Class \\
\hline $2000-1$ & John Carroll University & Separate Class & Separate Class \\
\hline $2000-1$ & Malone University & Separate Class & Separate Class \\
\hline $2001-2$ & Myers University & Separate Class & Separate Class \\
\hline $2001-2$ & Otterbein College & Separate Class & Separate Class \\
\hline 2000-1 & The University of Findlay & Integrated & Integrated \\
\hline $2001-2$ & Tiffin University & Separate Class & Separate Class \\
\hline 2000-1 & University of Dayton & Integrated & Separate Class \\
\hline $2000-1$ & Walsh University & Separate Class & Separate Class \\
\hline $2000-1$ & Xavier University & Separate Class & Separate Class \\
\hline
\end{tabular}

In response to the second research question, the study concluded that private institutions treat the issue of ethics instruction differently from that of public institutions. The vast majority of private institutions in Ohio (75\%) are affiliated with religious organizations with a long tradition of teaching ethics as part of their institutional mission. Analysis of their documentation and administrator interviews found that they typically teach ethics as a 
separate course in their core MBA curriculums. Study data also revealed that private institutions made very few adjustments to their core curriculums since the passage of the Sarbanes-Oxley Act of 2002. Instead, their traditional approach to ethics instruction conveniently placed them on the proper side of the issue after the passage of the Act.

Conversely, the majority of public institutions (81\%) initially approached ethics instruction by integrating the subject into existing core courses or by providing students with the opportunity to acquire it as an elective. In the six years since the passage of Sarbanes-Oxley, only two public institutions altered their position on the issue. These institutions chose to supplement their initial integrated teaching approach with a separate core ethics course. Administrators from these institutions cited the magnitude of recent corporate scandals and the subsequent public uproars as the reasons for these changes.

In summary, MBA programs in Ohio did not view the Sarbanes-Oxley legislation as a curriculum altering event and failed to react to the upheaval the legislation caused in the business community. MBA administrators misunderstood the leadership challenges embedded in the Act's sections and ultimately missed an opportunity to enhance the skills of their graduates.

\section{DISCUSSION OF RESULTS}

Each of the 27 colleges and universities included in this study were asked to select a representative best qualified to answer questions on curriculum, to participate in a ten question interview. Thirteen institutions responded favorably to this request. Thirty-eight percent or six private institutions agreed to interviews while sixtyfour percent or seven state-sponsored institutions granted interviews. One institution agreed to have two individuals interviewed. Table 3 details the positions held by the individuals involved in the interview process. Seventy-one percent of the interviewees held positions as either the MBA Program Director or Associate/Assistant Dean of their respective schools of business. Each administrator was given the opportunity to explain how ethics was taught in their MBA programs. In response to this question, 8 of the 13 institutions or approximately $62 \%$ responded that ethics was taught as a separate course in their core curriculum. Some of these administrators reported that they also supplement their stand-alone core course with an integrated teaching approach. One administrator reported that her institution taught a required ethics course to all their MBA students but they did not consider it a part of their core curriculum. Since this course could not be waived and was required for graduation, this institution was classified, for the purposes of this study, among those offering an ethics class as part of their core curriculum.

Table 3: Administrative Positions involved in Interview Process

\begin{tabular}{lc}
\hline Position at Institution & Number \\
\hline MBA Program Director & 6 \\
MBA Program Chair & 2 \\
Associate/Assistant Dean & 4 \\
Director Graduate Programs & 1 \\
Graduate Coordinator & 1 \\
\hline
\end{tabular}

The study found that three institutions in Ohio changed their positions on ethics instruction by adding it as a separate core course after 2002; two of these universities were public and one was private. As a result, the number of institutions now teaching ethics as a separate class in their core curriculums increased from 14 to 17 respectively. This shift represented an $11 \%$ increase over the base year period. The key effort of the interview process was to identify the causes for this change and the reasons for the institutions current position on the issue.

An explanation to the above issues came in the form of five themes that emerged from the interview data. First, MBA administrators did not alter their curriculums in response to the Sarbanes-Oxley legislation because they do not believe that ethics can be taught. When asked what role MBA programs played in shaping the ethical behavior of business leaders approximately $79 \%$ of the respondents stated that MBA programs cannot teach ethics. Further, they argued that the best result an MBA program can achieve is to influence ethical behavior. Their position reflect Cragg's (1997) argument that college students arrive on campus with fully developed characters and Ritter's (2006) contention that colleges and universities cannot alter character lessons learned early in a student's 
life by their participation in one college-level ethics class or the partial infusion of ethics into many classes. Most administrators stated that MBA programs can only provide students with the tools to influence moral decision making. When asked what factors were most responsible for shaping the ethical behavior of business leaders, MBA administrators defended their curriculums by citing the social institutions of family and church as the leading factors. Their reasoning supported the argument made by Velasquez, Andre, Shanks, and Meyer (1987) that students learn ethics during their formative years through interaction with parents, churches, and elementary schools.

Only two administrators interviewed (14\%), believed that ethics could be taught at the MBA level. One administrator stated that he believed MBA programs play a significant role in shaping leadership behavior and have a life-long impact on graduates. The second stated that ethical behavior should be a "key by-product" of the MBA experience. Each of these positions are supported by experts such as Aristotle (Nicomachean Ethics 1105b), Plato (Kemerling, 2001); Swanson (2004); Rynes (2003). Despite the moral attractiveness of their arguments, these two individuals' represented the minority position among administrators interviewed. The majority believe that ethics cannot be taught and direct their programs to influence rather than teach behavior.

The impact of Ohio's majority position limits the potential of its MBA programs and the options available to ethics instruction and ultimately the business community. First, MBA programs which only strive to teach the tools of decision making avoid the conflicts that push students to the point of behavioral change. Such conflict introduces stress and confusion to the learning process and requires a strong guiding force to achieve success. Churchill (1982) stated that the guiding force needed to succeed in this endeavor is the bond created between the student and the teacher and forging this bond requires effort from both parties. Instructors can use such techniques as case studies and role plays to place students in uncomfortable situations that teach the drawbacks of unethical decisions; a task is made easier when curriculums are constructed to support these teaching methods.

Ohio's majority position limits the options available to the business community because many MBA graduates lack the skills needed to be effective ethical decision makers. Effective decisions of this type require an evaluation of all the factors that impact a given situation. Often, even the simplest decisions have unexpected ethical consequences. MBA programs that continually enable their students to experience the consequences of decision making increase the likelihood that appropriate behavior will find its way into the workplace and decrease the likelihood employers will have to retrain employees to avoid undesirable results. As Aristotle said in his work Nicomachean Ethics, "for it is only doing by just acts that the just man is produced" (1105b).

The second theme to emerge from the data was that MBA program administrators do not look to legislation as a source for curriculum change. All of the administrators interviewed stated that the Sarbanes-Oxley legislation was a regulatory issue not an academic issue. Further, 36\% stated that "Sarbanes-Oxley was purely accounting related legislation" not one intended to influence core curriculums. One interesting fact that emerged from the interviews was that very few administrators had researched the legislation. Only one individual possessed a full appreciation for the consequences of the legislation on the business community. It came as no surprise the curriculum at this individual's institution was one of the most progressive in this area.

As a businessman conducting this study, I was surprised by the reaction of MBA administrators to the Sarbanes-Oxley legislation. The legislation provided educators with a new market for their services and for their graduates. The Sarbanes-Oxley legislation exposed a need for employees capable of building support systems at an organizational level as well as being capable of making ethical decisions. Instead of reacting to this opportunity, educators lost this market to accounting firms and a host of professional training organizations. Finally, all the administrators interviewed stated that the Sarbanes-Oxley legislation was not a factor in making core curriculum decisions. One individual in particular stated that program administrators are too busy to concern themselves with the potential impact of legislation such as the Sarbanes-Oxley Act. Another analogized it to an unfunded mandate. It is evident from such comments that MBA administrations failed to realize that business organizations were undergoing massive organizational changes in response to the Act and missed an opportunity to provide an additional service to the business community. One can only hope that they have learned from such mistakes and will look for opportunity in equally difficult legislation. 
The third theme to emerge from the research was that the majority of program administrators did not view unethical behavior as MBA curriculum failures. Instead, they argued that the MBA experience did not significantly impact behavior. Among the 14 administrators interviewed, only $28.6 \%$ believed that the MBA experience played a major role in shaping a leader's ethical behavior, while the majority (71.4\%) stated that the experience played a small to moderate role. These opinions were surprising given the stature MBA graduates hold in the business community. Typically, employers pay a premium for MBA graduates because they are expected to have the skills needed to make difficult decisions. Although studies found that simply having an MBA was no guarantee of financial success or career advancement, fellow employees look to MBA graduates as role models and emulate their actions (Nohria \& Eccles, 1992). As a result, when business leaders act unethically, their behavior reflects upon themselves, the institutions they represent, and the curriculum used to prepare them for the workplace (Ghoshal, 2005; Mintzberg, 2004; Pfeffer \& Fong, 2002). ).

Additional evidence supporting this theme surfaced when MBA administrators were asked if their institutions initiated any actions in response to the Rutgers Study (McCabe, Butterfield, \& Trevino, 2006), and the Duke University cheating probe (Keenan \& Sullivan, 2007); two nationally publicized events detailing unethical behavior by MBA students. All of the institutions surveyed stated that they did not see evidence of cheating in their programs and that no curriculum adjustments were planned. When asked if the results of the Rutgers Study and the Duke University cheating probe were indictments on the MBA curriculum, the overwhelming reaction of MBA administrators was to defend their current curriculums. This position stands in contrast with the finding of the study conducted by McCabe, Butterfield, and Trevino, which concluded that MBA students cheat more than graduate students from other disciplines. Also, the positions of Ohio's MBA administrators on this issue stands in sharp contrast to the old adage "where there is smoke there is fire".

The fourth theme to emerge from the data was the belief among MBA administrators that accreditation organizations should not increase their roles in defining the ethics requirements for MBA programs. Seventy-five percent of the administrators interviewed stated that the present level of involvement by accreditation organizations was sufficient to ensure that MBA curriculums adequately addressed ethics. One administrator stated that accreditation organizations are already too involved in the process. While another stated that he viewed additional involvement by accreditation organizations the same way he viewed Sarbanes-Oxley, "as an attempt at legislated ethics". Ohio's MBA administrators' should reexamine their position on accreditation organizations and value their standards as opportunities to improve. These standards are analogous in meaning to those of the International Organization for Standardization (ISO) used by businesses to improve their quality processes. ISO standards enable businesses to improve product reliability, manufacturing processes, and increase customer satisfaction. Also, ISO certified companies can use their certification to expand into markets that would otherwise remain closed. Similar advantages can be achieved by MBA programs. Using accreditation organizations to increase the ethical content of core curriculums can strengthen the program's standing among potential students and employers. MBA programs with strong ethics components can become the preferred source among employers for job candidates. Also, students may seek out such programs knowing that an MBA program, which among other qualities has a strong ethical component, will better prepare them to make difficult decisions in the workplace; a desired result according to a recent survey by the Aspen Institute (2008). Administrators must look past their bias for minimal involvement by accreditation organizations (Altbauch, Berdahl, \& Gumprot, 2005) and seek new achievement benchmarks. As one Ohio administrator, advocating a minority opinion, put it, "what gets measured gets done".

The last theme to emerge from the research was the fact that MBA curriculums in private institutions handle the issue of business ethics differently than public institutions. Base period data showed that 13 of the 16 (81\%) private institutions taught ethics as a separate class in their core curriculums prior to the passage of the Sarbanes-Oxley Act of 2002. One explanation for this finding was the fact that 12 of the 16 (75\%) MBA programs in Ohio are affiliated with religious organizations and $92 \%$ of these institutions now teach ethics as a separate course in their core curriculums. Administrators representing religious affiliated MBA programs stated that ethics education was always a part of their educational mission and, therefore, a separate course in business ethics or a combination of a separate course with ethics integrated into other coursework was a natural fit for their core curriculums. Further, they contended that stand-alone courses ensured adequate coverage of the desired material, a position supported by some experts. Baetz and Sharp (2004), advocated that the primary advantage of a single stand-alone ethics course is that it is easier to administer from an institutional perspective than an integrated teaching approach. 
During the base period for this study, 8 of the 11 (73\%) public institutions relied solely upon an integrated approach to teaching ethics in their MBA programs. Today, only 54\% continue to rely on this approach. Administrators representing public programs were uncomfortable explaining their institution's choice of teaching methods; however, some explanation is found in the literature. The rationale for integrating ethics into a broad range of classes is to emphasize the importance it has to the entire curriculum experience (Evans, Trevino, \& Weaver, 2006: McDonald, 2004). Programs adopting this approach incorporate ethics into each element of their curriculum and review issues surrounding ethics legislation as part of their obligation to teach students about legal and regulatory issues that impact organizations (Baetz \& Sharp, 2004). McDonald (2004) stated that supporters of this argument believe students benefit from the exposure to relevant ethical problems and the experience of developing specific solutions to each situation. Also, subject integration is secular in nature. Relying on many instructors to convey ethical messages makes it difficult to argue that the MBA programs are advocating religious beliefs. Integration of this type takes on a Kantian appeal that becomes a safe harbor for instructors by advocating reason over morality.

The positions taken by private and public institutions in their approach to teaching ethics changed little during the period covered by this study. Twenty-four of the 27 (89\%) institutions surveyed stated they believed their curriculums adequate to teach business ethics. Today, 14 of the 16 private institutions and 4 of the 11 public institutions teach ethics as a separate course in MBA curriculums. This represents $6.2 \%$ and $18 \%$ increase for these respective groups. Data analysis also revealed that when changes did occur in private institutions they took one of the following three forms (a) a separate class, (b) an integrated teaching approach to supplement a preexisting core ethics class, or (c) a seminar. These are the same techniques used by public institutions. Even the pace of change was similar between the two types of institutions. During the period covered by this study, only one private and two public institutions changed their teaching techniques.

\section{SUMMARY}

In summary, the study concluded that colleges and universities have not adjusted their curriculums in response to the Sarbanes-Oxley legislation passed by Congress to curb the tide of unethical practices by business leaders. The first reason for this conclusion was that some MBA programs in Ohio were teaching ethics in their core curriculums before the scandals and the Sarbanes-Oxley legislation. Analysis revealed that on a percentage basis Ohio MBA programs included ethics as a core course in their curriculums $12 \%$ more often than the top 50 national MBA programs in the base period and $23 \%$ more often in the current academic year (Navarro, 2008). This fact explains in part the slow reaction to the legislation by some institutions. Also, traditions upon which the majority of Ohio MBA curriculums were built, those of religiously affiliated institutions, left little to adjust after the passage of the Act. A second reason is that the majority of MBA program administrators do not believe that ethics can be taught, and direct their programs to influence decision making processes instead of shaping behavior. Third, MBA program administrators do not look to legislation for guidance in making curriculum decisions, especially when the legislation is complex and the reasons for change are not clear. Fourth, MBA administrators felt immune to criticism of their curriculums. They believed unethical behavior was not the fault of curriculums and that existing curriculums were adequate to address the ethical needs of students. Fifth, MBA administrators believe ethics instruction to be an institutional matter and are not looking for guidance from their accreditation organizations. Finally, private institutions in Ohio have traditionally treated the subject of ethics instruction in core MBA curriculums differently than public institutions. As a result, two very different approaches to teaching ethics remain within Ohio's MBA program system. Teaching ethics, as a core curriculum course, is the preferred method of instruction in private institutions and integrating ethics into other core curriculum courses is the preferred teaching method in public institutions.

\section{RECOMMENDATIONS FOR EDUCATORS}

The Sarbanes-Oxley Act of 2002 was an unlikely place for MBA program administrators to look for curriculum change. The Act was long and complex and was closely associated in the media with a number of highly publicized accounting related corporate scandals. On the surface it was regulatory in nature but its implications were more far reaching. Many organizations had to transform their current operations from the ground up to achieve compliance. In the future, educators should keep a watchful eye for legislation that creates large amounts of turmoil 
within the business community. After 33 years as a businessman I have learned that within such chaos lies opportunity. Educators should look for these opportunities to assist business leaders with compliance. Second, transforming a traditional business organization into an ethics based organization requires leadership, support systems, new personnel policies, and an understanding of business ethics. Each of these elements share an integral and complex relationship with the other.

Ohio's educators for the most part missed this relationship when evaluating the Sarbanes-Oxley legislation and dismissed it as regulatory or simply as an accounting issue. Leaders need ethical skills to build ethical organizations. MBA program administrators must not assume that these skills were acquired through the past experiences of their students. They must assess the current landscape and make the curriculum changes necessary to allow their students to succeed. In today's fast pace global environment, change comes quickly and skills become obsolete. Educators must make the changes necessary to keep pace. Although Ohio's institutions included ethics as a core course in their curriculums more often than institutions nationally, two very different approaches to teaching ethics remain within the Ohio's MBA program system. Educators should attempt to reach consensus on one approach and make the student experience more consistent. Finally, educators should look at situations similar to the Sarbanes-Oxley experience as opportunities to bridge the gap between the needs of the business community and the educational product.

\section{AUTHOR INFORMATION}

Daniel W. Sullivan is an experienced business and academic professional. He began his business career as an hourly employee for General Motors in the mid 1970's and advanced through corporate assignments in Finance, Engineering, Quality Assurance, Facilities Management, and Manufacturing throughout a 33 year career. Currently, Dr. Sullivan is a management instructor at Ashland University's Richard E. \& Sandra J. Dauch College of Business \& Economics. He holds an Economics degree from the University of Pittsburgh, an MBA from Indiana University of Pennsylvania, a J.D. from the University of Akron, and an Ed.D. in Organizational Leadership from Ashland University.

\section{REFERENCES}

1. Alsop, R. (2003, 17 September). The top business schools (a special report); Right and wrong: Can business schools teach students to be virtuous? In the wake of all the corporate scandals, they have no choice but to try. The Wall Street Journal, p. R1.

2. Altbach, P.G., Berdahl, R.O., \& Gumport, P.J. (Eds). (2005). American higher education in the twenty-first century: Social, political, and economic challenges (2nd ed.). Baltimore, MD: John Hopkins University Press.

3. Aristotle (1962). Nicomachean Ethics. (M. Ostwald, Trans.). Englewood Cliffs, NJ: Prentice Hall.

4. The Aspen Institute (2008). Where will they lead? MBA student attitudes about business and society. Retrieved December 27, 2008, from http://www.aspencbe.org/documents/ExecutiveSummaryMBAStudentAttitudesReport2008.pdf

5. Baetz, M.C., \& Sharp, D.J. (2004). Integrating ethics content into the core business curriculum: Do core teaching materials do the job? Journal of Business Ethics, 51, 53-62.

6. Beggs, J.M., \& Dean, K.L. (2007). Legislated ethics or legislated education? Faculty views in the postEnron era. Journal of Business Ethics, 71, 15-37.

7. Churchill, L.R. (1982). The teaching of ethics and moral values in teaching: Some contemporary confusions. Journal of Higher Education, 53, 296-306.

8. Cragg, W. (1997). Teaching business ethics: The role of ethics in business and in business education. Journal of Business Ethics, 16, 231-245.

9. Devaney, M. (2007, December). MBA education, business ethics and the case for shareholder value. Journal of Academic Ethics, 5, 199-205.

10. Evans, J.M., Trevino, L.K., \& Weaver, G.R. (2006). Who's in the ethics driver's seat? Factors influencing ethics in MBA curriculums. Academy of Management Learning \& Education, 5(3), 278-293.

11. Friedman, S.D. (1996). Community involvement projects in Wharton's MBA curriculum. Journal of Business Ethics, 15, 95-101. 
12. Ghoshal, S. (2003, 18 July). Business schools share the blame for Enron. Financial Times. Retrieved June 14, 2007 from http://www.southerninstitute.org/Resources-GoodBusiness-Content(21).htm

13. Ghoshal, S. (2005). Bad management theories are destroying good management practices. Academy of Management Learning and Education. 4(1), 75-92.

14. Keenan, M., \& Sullivan, B.K. (2007, 1 May). Duke probe shows failure of post-Enron ethics classes. Bloomberg.com. Retrieved November 15, 2008 from http://www.bloomberg.com/apps/news?pid=20601103\&sid=aEL5ZnKhQuXY\&

15. Kemerling, G. (2001). Philosophy Pages. Retrieved June 30, 2007 from hppt://philosophypages.com/hy/2f/htm

16. Leonard, A. (2001, 2 December). Traditional or not, MBA curriculums vary widely. Chicago Daily Herald. Retrieved May 27, 2007 from http://www.kellogg.northwestern.edu/news/hits/011202cdh.htm

17. Maxwell, J.A. (1992). Understanding and validity of qualitative research. Harvard Educational Review, 62(3), 279-300.

18. McCabe, D.L., Butterfield, K.D., \& Trevino, K.L. (2006). Academic dishonesty in graduate business programs: Prevalence, causes, and proposed action. Academy of Management Learning \& Education, 5(3), 294-305.

19. McDonald, G.M. (2004), A case example: Integrating ethics into the academic business curriculum. Journal of Business Ethics, 54, 371-384.

20. Merriam, S.B. (1998). Qualitative research and case study applications in education. San Francisco: Jossey-Bass.

21. Mintzberg, H. (2004). Managers, not MBAs. San Francisco: Berrett-Koehler Publishers, Inc.

22. Navarro, P. (2008, 22 April). Business schools: A study in failure. Devotion to traditional subjects means leadership, social responsibility, ethics, and a global view get short shrift in the MBA curriculums. BusinessWeek. Retrieved December 8, 2008 from http://www.businessweek.com/bschools/content/apr2008/bs20080422_496936.htm?chan=search

23. Nohria, N., \& Eccles, R.G. (1992). Face-to-face: Making network organizations work. In N. Nohria \& R.G. Eccles (Eds.), Networks and Organizations (288-308). Boston: Harvard Business School Press.

24. Pfiffer, J., \& Fong, C.T. (2002). The end of business schools? Less success than meet the eye. Academy of Management and Learning and Education, 1(1), 78-89.

25. Ritter, B.A. (2006). Can business ethics be trained? A study of the ethical decision making of business students. Journal of Business Ethics, 68, 153-164.

26. Rynes, S.L., Trank, C.Q., Lawson, A.M., \& Ilies, R. (2003). Behavior coursework in corporate education: Growingevidence of legitimacy crisis. Academy of Management Learning and Education, 2(3), 269-283.

27. Segev, E., Raveh, A., \& Farjourn, M. (1999). Conceptual maps of the leading MBA programs in the United States: Core courses, concentration areas, and the ranking of the school. Strategic Management Journal, 20,549-565.

28. Swanson, D.L. (2004), The buck stops here: Why universities must reclaim business ethics education. Journal of Business Ethics, 2, 43-61.

29. Velasquez, M., Andre, C., Shanks, T., \& Meyer, M.J. (1987, Fall). Can ethics be taught. Issues in Ethics. Retrieved on May 26, 2008 from http://www.scu.edu/ethics/practicing/decision/canethicsbetaught.html 
NOTES 